\title{
Nilai-Nilai Kearifan Lokal Masyarakat Adat Kampung Naga sebagai Alternatif Sumber Belajar
}

\author{
LELLY QODARIAH DAN LAELY ARMIYATI \\ FKIP Universitas Muhammadiyah Prof. Dr. HAMKA \\ e-mail : laelyarmy@yahoo.co. id
}

\begin{abstract}
Abstrak
Tujuan penelitian yaitu 1)Mengetahui sejarah dan karakteristik kearifan lokal masyarakat Kampung Naga; 2)Memperoleh nilai-nilai kearifan lokal yang dapat diintegrasikan dalam mata pelajaran IPS; 3) Menjadikan kearifan lokal pada Masyarakat Kampung Naga sebagai alternatif sumber belajar IPS. Metode yang digunakan adalah kualitatif deskriptif. Hasil penelitian yaitu 1) Masyarakat Kampung Naga memiliki kearifan lokal terkait dengan kepemimpinan, interaksi sosial, dan tata cara hidup; 2) nilai-nilai kearifan lokal di dalamnya meliputi kepedulian lingkugan, kerjasama, konsisten, kreativitas, kemandirian, kebersamaan, kesederhanaan, dan tanggungja wab; 3) nilai-nilai kearifan lokal tersebut dapat diintegrasikan dalam materi mata pelajaran di kelas VII dan VIII, sehingga masyarakat Kampung Naga dapat menjadi alternatif sumber belajar IPS. Kata kunci: Pembelajaran IPS, Kearifan Lokal, Sumber Belajar
\end{abstract}

\begin{abstract}
This research aims to 1) investigate the history and characteristics of local wisdom in Kampung Naga society; 2) find out the local wisdom values which can be integrated in Social Studiessubject; 3) use local wisdom values of Kampung Naga society as alternative of Social Studies learning sources in Tasikmalaya. The method utilized in this research is qualitative descriptive. The findings are (1) Kampung Nagasociety has local wisdom which include leadership, social interaction, and the way of life; (2)the local wisdom values consist of environmentally friendly, good cooperation, consistency, creativity, togetherness, autonomous, simplicity, and responsibility; and (3) local wisdom of Kampung Naga's society can be integrated in learning materials for grade VII and VIII therefore Kampung Naga society can become learning sources of Social Studies subject.

Keywords: social studies teaching, local wisdom, learning sources
\end{abstract}




\section{PENDAHULUAN}

Definisi pendidikan yang tercantum dalam Undang-Undang Republik Indonesia Nomor 20 Tahun 2003 tentang Sistem Pendidikan Nasional, pasal 1, butir 1 (Darwanto, 2007:90) adalah usaha sadar dan terencana untuk mewujudkan suasana belajar dan proses pembelajaran, agar peserta didik secara aktif mengembangkan potensi dirinya untuk memiliki kekuatan spiritual keagamaan, pengendalian diri, kepribadian, kecerdasan, akhlak mulia, serta ketrampilan yang diperlukan dirinya, masyarakat, bangsa, dan negara. Pengertian tersebut menegaskan bahwa pendidikan bertanggungjawab atas perubahan perilaku dalam segala aspek kehidupan peserta didik, termasuk perilaku dalam domain sosio kultural.

Tersamarnya identitas nasional sebagai jati diri bangsa Indonesia pada generasi muda Indonesia, menjadi bahan perbinca ngan dalam forum-forum diskusi. Dirunut penyebabnya, salah satu diantaranya adalah masuknya budaya asing secara masif dan tanpa filter yang benar. Akibatnya, tumbuh sikap-sikap yang bertolak belakang dengan jati diri bangsa, seperti materialisme, hedonisme, dan individualisme. Hal ini kelak akan menjadi bumerang bagi dirinya dan bangsa Indonesia secara keseluruhan. Karena, ketika seseorang sudah tidak peduli dengan yang lain, kehidupan harmonis dan adil tidak akan mampu terwujud. Itulah mengapa diperlukan suatu pembelajaran yang menyadarkan kembali generasi muda terkait identitasnya sebagai manusia Indonesia, salah satunya melalui pembelajaran berbasis kearifan lokal.

Indonesia memiliki warisan budaya yang sangat melimpah yang tertuang dalam berbagai bentuk baik berupa artefak (tangible) maupun tradisi (intangible) yang terungkap dalam masyarakat adat. Keberadaan masyarakat adat di Nusantara, selayaknya dia presiasi oleh para peneliti dan akademisi, tidak hanya dipergunakan sebagai komoditi materi dengan menjadikannya heritage tourism, tetapi yang terpenting adalah upaya memaknai warisan budaya leluhur, menggali nilai-nilai positif, guna dijadikan pedoman dalam menemukan jati diri bangsa.

Kampung Naga merupakan salah satu wilayah tempat berdiamnya masyarakat adat. Wilayah yang terletak di Kabupaten Tasikmalaya, telah dijadikan sebagai tempat penelitian bagi akademisi professional dan amatir yang tertarik dengan pola hidup masyarakat adat. Masyarakat Kampung Naga merupakan salah satu bagian dari Suku Sunda, memiliki tradisi tangible dan intangible yang masih dipelihara. Eksistensi tradisi masyarakat Kampung Naga di tengah globalisasi, menarik untuk dilihat dari sudut pandang pendidikan. Dalam hal ini terkait dengan memaknainya sebagai warisan budaya yang bisa dijadikan alternatif sumber pembelajaran IPS di wilayah Tasikmalaya. Tujuan dari penelitian ini adalah sebagai berikut:

1. Mengetahui sejarah dan karakteristik kearifan lokal masyarakat Kampung Naga.

2. Memperoleh nilai-nilai kearifan lokal yang dapat diintegrasikan dalam mata pelajaran IPS

3. Menjadikan kearifan lokal pada masyarakat Kampung Naga sebagai alternatif sumber belajar IPS.

\section{KEARIFAN LOKAL}

Kearifan lokal berasal dari dua kata yaitu kearifan (wisdom), dan lokal (local). Secara umum maka local wisdom (kearifan lokal) dapat dipahami sebagai gagasan-gagasan setempat (local) yang bersifat bijaksana, penuh kearifan, bernilai baik, yang tertanam dan diikuti oleh anggota masyarakatnya. Keberadaan kearifan lokal ini bukan tanpa fungsi. Kearifan lokal sangat banyak fungsinya. Seperti yang dituliskan Sartini (2006), bahwa fungsi kearifan lokal adalah (1) konservasi dan pelestarian sumber daya alam; (2) pengembangan sumber daya manusia; (3) pengembangan kebudayaan dan ilmu pengetahuan; (4) petuah, kepercayaan, sastra dan pantangan; (5) bermakna sosial misal nya upacara integrasi komunal/kerabat; (6) bermakna etika dan moral; (7) bermakna politik, misalnya upacara ngangkuk merana dan kekuasaan patron client. 
Atmodjo (1986: 37), kearifan lokal merupakan kemampuan penyerapan kebudayaan asing yang datang secara selektif, artinya disesuaikan dengan suasana dan kondisi setempat. Kemampuan demikian sangat relevan dengan tujuan pembelajaran IPS, dengan kemampuan tersebut akan menyebabkan peserta didik dapat memilih dan memilah budaya mana yang sesuai dengan karakteristik budaya sendiri. Kemampuan penyerapan kebudayaan asing yang datang secara selektif tentu memerlukan pengalaman langsung dari masyarakat sekitar tempat tinggalnya. Hal itu dapat dilakukan dengan mengguna kan budaya masyarakat adat sebagai sumber belajar.

\section{Kearifan Lokal sebagai Sumber Belajar IPS}

Implementasi nilai-nilai budaya lokal dalam pembelajaran IPS dapat dikaji dari filsafat pendidikan yang mendasarinya yaitu Perenialisme.

Perenialisme memandang pendidikan sebagai proses yang sangat penting dalam pewarisan nilai budaya terhadap peserta didik. Nilai-nilai budaya yang dimiliki oleh masyarakat sangat penting ditransfromasikan dalam pendidikan, sehingga diketahui, diterima dan dapat dihayati oleh peserta didik. Perenialisme memandang bahwa masa lalu adalah sebuah mata rantai kehidupan umat manusia yang tidak mungkin diabaikan. Masa lalu adalah bagian penting dari perjalanan waktu manusia dan memiliki pengaruh kuat terhadap kejadian masa kini dan masa yang akan datang. Nilai-nilai yang lahir pada masa lalu adalah hal yang berharga untuk diwariskan kepada generasi muda.

National Council for Social Studies (NSCC) mendefinisikan Ilmu Pengetahuan Sosial sebagai berikut:

Social studies as "the integrated study of the social science and humanities to promote civic competence". Within the school program, social studies provides coordinated, systematic, study drawing upon such disciplines as anthropology, archeology, economics, geography, law, philosophy, political science, psychology, religion and sociology, as well as appropriate content from the humanities, mathematic and natural sciences. (Savage, 1996: 9)

Dari definisi tersebut, dikatakan bahwa melalui pembelajaran Ilmu Pengetahuan Sosial, peserta didik diajarkan untuk menjadi warga Negara Indonesia yang baik dan penuh kedamaian. Ilmu Pengetahuan Sosial diperlukan bagi keberhasilan transisi kehidupan menuju pada kehidupan yang lebih dewasa dalam upaya membentuk karakter bangsa yang sesuai dengan prinsip dan semangat nasional. Dengan demikian para peserta didik dalam pembelajaran IPS terlatih untuk menyelesaikan persoalan sosial dengan pendekatan secara holistik dan terpadu dari berbagai sudut pandang.

Ruang kajian IPS adalah manusia, ruang, dan waktu, dimana ketiganya jika digabungkan memiliki sifat dinamis, meskipun statis dari segi fisik. Oleh karena kedinamisannya, pembelajaran IPS memiliki materi yang sa ngat padat dan kompleks, sebab mempelajari kedinamisan manusia dari masa ke masa dan ruang ke ruang. Sumber belajar dalam IPS tidak hanya berupa buku, tetapi perilaku masyarakat sekitar dan kearifan lokal yang ada di sekitarnya. Terkait dengan kearifan lokal, pemanfaatannya sebagai sumber belajar dapat pula dijadikan bagian dalam pendidikan karakter yang hendak dikembangkan guru.

\section{Kondisi Geografis Kampung Naga}

Secara administratif Kampung Naga masuk dalam pemerintahan desa/ kelurahan Neglasari, Kecamatan Salawu, Kabupaten Tasikmalaya, Jawa Barat. Secara geografis, Kampung Naga terletak di sebuah lembah yang jaraknya $\pm 1 \mathrm{~km}$ dari jalan raya dengan ketinggian 488 meter dari permukaaan laut. Wilayah ini terdiri atas lahan permukiman, lahan persawahan, empang, bukit dan hutan. Di sebelah barat, Kampung Naga berbatasan dengan bukit Naga. Sebelah timur berbatasan dengan sungai Ciwulan dan hutan lindung (pembatas antara Kampung Naga dan kampong Babakan). Sebelah selatan berbatasan dengan bukit dan jalan raya TasikmalayaBandung, lewat Garut. 
Desa Neglasari terdiri atas empat dusun, yaitu dusun Naga, Cikeusik, Surakarta, dan Tajuk Nangsi. Dusun Naga memiliki lima Rukun Tangga (RT), yaitu Lodok Gede, Babakan, Pondok Wani, Batar Sani, dan Kampung Naga. Luas areal Kampung Naga \pm 10 hektar, terdiri dari hutan, pertanian, dan perikanan. Sedangkan untuk lahan pemukiman luasnya sebesar 1,5 hektar. Penduduk Kampung Naga mendiami rumah berbentuk panggung yang berjumlah 113 buah, membujur dari barat ke timur dengan pintu rumah menghadap ke utara atau ke selatan.

\section{Sejarah Kampung Naga}

Terdapat banyak versi terkait asal mu asal masyarakat Kampung Naga. Berdasarkan wawancara dengan punduh (28 Februari 2013), ini dikarenakan, bukti tertulis yang konon ditulis di atas daun lontar sudah terbakar habis ketika peristiwa 1956, yaitu peristiwa dibakarnya Kampung Naga oleh gerombolan DI Kartosuwiryo. Kampung Naga kemudian dibangun kembali dengan tetap menerapkan ketentuan dan bentuk pemukiman seperti sebelumnya. Kesulitan untuk melacak asal usul penduduk Kampung Naga juga karena tidak adanya kebiasaan membicarakan asal usul nenek moyang kepada orang umum (masyarakat biasa). Versi pertama, Seuwu Putu Naga (sebutan untuk penduduk Kampung Naga), berasal dari Mataram. Konon ceritanya pada tahun 1630 ketika Sultan Agung menyerang Batavia, sekelompok pasukan Mataram di bawah pimpinan Singaparna mengalami kekalahan. Pasukan tersebut tidak kembali ke Mataram dan tidak pula menyerahkan diri pada VOC, melainkan bersembunyi di sebuah hutan perbukitan di dekat sungai Ciwulan. Untuk menutupi identitasnya, mereka mengubah nama dan dialek mereka dengan Sunda. Sejak itu, penduduk tidak diperbolehkan menyebut nama Singaparna dan menyebut kampung mereka de ngan Kampung Naga (Haditomo, 1989: 31).

Versi kedua, Eyang Singaparna yang merupakan karuhun (nenek moyang) me reka berasal dari Timur -dipercayai dari Mataram. Ia bertugas sebagai utusan raja untuk menyebarkan agama Islam ke Tanah Pa- sundan. Dalam perjalanan, ia sampai di suatu daerah yang merupakan daerah cekungan, di tempat itu ia mendirikan sebuah bangunan sebagai tempat tinggalnya, hingga kini dikenal dengan bumi ageung, yang menjadi ba ngunan pertama masyarakat Kampung Naga (Budi Sulistiono, 1997:11).

Versi ketiga, penduduk asli Kampung Naga berasal dari lereng gunung Galunggung, orang Sunda asli, berasal dari keturunan $\mathrm{Si}$ ngaparna. Singaparna adalah nama ulama sakti, putra Prabu Rajadipuntang yang merupakan Raja Galunggung terakhir. Prabu Raja dipuntang diserang oleh Prabu Surawisesa dari Kerajaan Sunda, karena tidak lagi memeluk agama Hindu dan beralih pada agama Islam, peristiwa ini berlangsung pada abad ke- 16 Masehi. Menghadapi serangan tersebut, Prabu Rajadipuntang menyelamatkan harta pusakanya dan menyerahkannya pada Singaparna, serta memintanya untuk menyelamatkan diri (Etty Saringendyanti, 2008:12).

Berdasarkan berbagai versi tersebut, peneliti mengambil beberapa kesimpulan. Pertama, adanya sosok Eyang Singaparna yang dipercayai sebagai karuhun (nenek moyang) atau primus interpares masyarakat Kampung Naga, hingga saat ini terdapat sebuah makam yang dipercayai adalah makan Singaparna, dan selalu diikutsertakan dalam berbagai kegiatan upacara. Kedua, Islam telah menjadi agama masyarakat Kampung Naga antara abad 16 hingga 17 Masehi. Ketiga, masyarakat Kampung Naga berasal dari suku Sunda, karena merupakan keturunan kerajaan Galunggung, kemudian terjadi pertemuan budaya dengan Jawa ketika pasukan Mataram menyerang Batavia dan meminta bantuan penduduk sekitar.

\section{METODE}

Penelitian ini menggunakan metode kua litatif deskriptif. Tempat penelitian yaitu di Kampung Naga, Desa Neglasari, Kecamatan Salawu, Kabupaten Tasikmalaya, Jawa Barat. Teknik pengumpulan data menggunakan wawancara, observasi, dan analisis dokumen. Analisis data dalam penelitian ini bersifat in- 
duktif melalui tiga proses yang bersifat siklik, yaitu reduksi data, sajian data, dan penarikan simpulan.

\section{HASIL DAN PEMBAHASAN}

\section{Kearifan Lokal Masyarakat Adat Kam- pung Naga}

\section{Tata Kelola Masyarakat Kampung Naga}

Berdasarkan observasi dan wawancara (28 Februari - 1 Maret 2013), masyarakat Kampung Naga menganut dualisme pengelolaan, dengan dua pemimpin yang memiliki tugas dan fungsi berlainan, yaitu pengelolaan secara adat yang dipimpin oleh kuncen, dan pengelolaan secara formal yang meliputi Kepala Desa, Ketua Rukun Tangga (RT), dan Ketua Warga (RW).

Pengelolaan secara adat dikendalikan oleh kuncen, yang merupakan pemimpin adat dan bertugas memimpin kehidupan seharihari masyarakat. Kuncen dibantu oleh lebe dan punduh. Lebe bertugas sebagai pelaksana teknik upacara perkawinan, kematian, dan membantu tugas kuncen jika berhalangan.

Punduh juga bertindak sebagai pembantu kuncen dalam urusan hubungan dengan masyarakat luar, termasuk tugasnya adalah hubungan dengan pemerintah dan menerima tamu dari luar Kampung. Pemilihan kuncen menggunakan sistem ascribed status.

Pemerintahan formal yang ada dalam masyarakat Kampung Naga adalah kepala desa, kepala kampung (Kuwu), RW, dan RT. Kepala pemerintahan diangkat sesuai prosedur peraturan pemerintah. Dualisme kepemimpinan yang ada dalam masyarakat Kampung Naga tidak lantas memunculkan konflik peran, karena adanya sikap saling pengertian tentang tugas dan wewenangnya.

Peran Kuncen di masyarakat Kampung Naga sebagai penjaga tradisi masih dijaga hingga saat ini. Bahkan, dalam pemilihan pemandu tour Kampung Naga pun harus atas restu Kuncen. Termasuk di dalamnya pemilihan tempat menginap, seperti yang disampaikan Ketua RT, pak Uron, menyampaikan dengan bahasa sunda "abdi teu wantun nampi tamu, upami parantos di piwarang ku pak kuncen, mangga di tampi. .. ", yang bermakna saya tidak berani menerima tamu, kecuali sudah diperintahkan oleh pak kuncen.

\section{Sistem Nilai Masyarakat Kampung Naga}

Sistem nilai adalah tata nilai yang dikembangkan oleh suatu komunitas masyarakat tradisional yang mengatur tentang etika penilaian baik-buruk atau benar-salah. Berdasarkan observasi dan wawancara (28 Februari - 1 Maret 2013), dalam masyarakat Kampung Naga sistem nilai diwariskan dalam dua bentuk, yaitu tangible (tampak) dan intangible (tidak tampak).

Pertama, sistem nilai berbentuk tangible, diwariskan dalam bentuk:

a) tekstual, yaitu kitab yang menceritakan asal usul Kampung Naga, tetapi kitab ini sudah tidak terdapat lagi, karena dikabarkan terbakar ketika kelompok DI Kartosuwiryo membakar desa (wawancara Ketua RT Kampung Naga).

b) bangunan/arsitektur rumah, Kampung Naga dikelilingi oleh pagar yang merupakan batas maksimal dibangunnya rumah. Batas ini telah ada sejak dahulu dan dibuat oleh leluhur mereka. Pagar batas tersebut menjadi patokan akhir bangunan rumah. Dengan demikian, luas pemukiman Kampung Naga selalu tetap, dengan jumlah bangunan maksimal yang disesuaikan dengan keberadaan pagar batas tersebut. Bangunan terbuat dari bilik bambu kepang dan sasag. Bilik sasag digunakan untuk bagian dapur, jalinan bambu dibuat dengan anyaman sasag, dapat memudahkan ventilasi dapur, sehingga udara bisa berganti dengan baik. Atap bangunan terbuat dari dua lapis, yaitu daun alang-alang, tepus, dan ijuk. Penggunaan bahan ini digunakan untuk menyerap hawa panas dan dingin, sehingga penghuni merasa nyaman ber ada di dalam. Tempat MCK (mandi, cuci, kakus), berada di luar rumah, dan merupakan milik umum, yang dibangun di atas empang, yang memiliki fungsi ganda, memberikan kemudahan karena tidak perlu membangun septic tank, juga se 
bagai upaya untuk memberi makan ikan yang hidup di empang tersebut. Kotoran yang dibuang manusia, akan langsung dimakan ikan. Dengan demikian, masyarakat mendapat kemudahan dalam mengatur sanitasinya.

c) Benda Tradisional, yaitu lesung, tungku tanah liat, semprong, kentongan, beduk, dan atap dari rumbia.

d) Kesenian, tradisi kesenian tidak hanya digunakan sebagai hiburan, tetapi juga memiliki makna dan tujuan yang berkaitan dengan religi mereka, diantaranya adalah Terbang gembrung yaitu kesenian tradisional dalam bentuk nyanyian menggunakan alat musik bernama terbangan berjumlah empat, tidak ceper atau tipis, tetapi agak bulat; Angklung; Beluk dan Rengkong, beluk merupakan salah satu kesenian yang mengangkat tembang sunda dengan nada-nada tinggi.

Kesenian ini biasanya dilakukan pada malam hari di rumah keluarga yang baru saja memperoleh bayi; Karinding, dimainkan dengan tujuan untuk memanggil hujan. Selain itu, juga terdapat upacara adat yang merupakan perpaduan antara Islam, Hindu, dan animisme. Upacara tersebut ialah Hajat Sasih, yang dilangsungkan enam kali tepat pada bulan-bulan besar bagi umat Islam, selain untuk menghormati leluhur, juga digunakan untuk silaturahmi penduduk sanaga -sebutan untuk keturunan Kampung Naga yang tinggal di luar Kampung)-; upacara life cycle, yaitu upacara kelahiran, perkawinan, dan kematian; dan upacara panen.

Pelaksanaan berbagai upacara ini, dilarang pada hari-hari tertentu, yaitu selasa dan kamis, yang dipercaya merupakan hari tidak diperbolehkannya membicarakan sejarah, asal-usul, dan berbagai tradisi adat Kampung Naga.

Kedua, sistem nilai berbentuk intangible, yaitu diwariskan dalam bentuk tidak berwujud, biasanya berupa petuah yang disampaikan dalam bentuk nyanyian atau petuah yang disampaikan secara oral atau lisan, turun temurun dari generasi ke gene rasi. Berikut adalah beberapa petuah yang hidup pada masyarakat Kampung Naga: (1)
Teu Saba, Teu Soba, Teu Banda, Teu Boga, Teu Weduk, Teu Bedas, Teu Gagah, Teu Pinter (tidak mengutamakan kehidupan materiil, tidak mengakui lebih dari yang lain, menjauhi perselisihan, dan cinta damai). (2) Nyalindung na Sihung Mahung, Diteker Nya Mementeng, Ulah Aya Guam (tidak boleh melawan walaupun mendapat hinaan dan berusaha menghindarkan diri dengan bersikap te nang). (3)Elmu tungtut dunya siar, nu goreng kudu disinglar (seseorang harus mencari ilmu sampai mendapatkan kearifan hidup, dengan demikian akan mampu membedakan yang baik dengan yang buruk, jika sudah tahu itu buruk, tidak baik, jahat maka harus dihindari).

\section{Tata Cara}

Terdapat tiga tata cara hidup masyarakat Kampung Naga, yaitu terkait dengan tata wilayah (penataan lahan), tata wayah (penga turan waktu), dan tata lampah (penataan perilaku), dalam konsep masyarakat Sunda, analogi konsep tata cara adalah pamali, artinya adalah tidak ada argumen jelas, karena sifatnya adalah turun temurun.

a) Tata wilayah, mengatur sistem pemukiman dalam tiga kawasan, yaitu kawasan suci bukit kecil di sebelah barat pemukiman disebut dengan Bukit Naga dan hutan lindung (leuweung larangan) yang terletak di sebelah timur dan barat sungai Ciwulan; kawasan bersih, yaitu kawasan yang terletak di dalam pagar keli ling, dan terhindar dari kotoran hewan ternah, di kawasan ini didirikan rumah, bale ageung, bale patemon, dan masjid; kawasan kotor, yaitu kawasan yang berada di luar pagar, terdapat empang (ko lam ikan), kandang kambing, dan tempat MCK.

b) Tata wayah, diantaranya dilakukan dalam pengaturan sistem tanam padi, yang disebut dengan Janli, akronim dari Januari-Juli.

c) Tata lampah, diantaranya adalah lara ngan sombong, larangan saling bertengkar, tidak boleh selonjoran menghadap ke Barat, larangan berbicara sejarah dan asal usul Kampung Naga pada hari selasa dan Kamis, larangan menggunakan 
listrik,larangan mengubah arsitektur bangunan, larangan memasuki bumi ageung dan hutan larangan, selain itu juga terdapat anjuran yaitu menghormati dan melayani tamu, menjalankan ibadah, menghormati leluhur, dan mematuhi Kuncen.

\section{Ketentuan Khusus}

Masyarakat Kampung Naga memiliki empat tempat yang dianggap keramat, yaitu kawasan larangan, yaitu hutan yang terletak di seberang sungai Ciwulan, dan bukit yang terletak di Barat pemukiman; bumi ageung; bumi pasolatan, dan bekas tempat menumbuk padi.

\section{Pemanfaatan Kearifan Lokal sebagai Sumber Belajar}

Berdasarkan observasi dan wawancara (28 Februari - 1 Maret 2013), wilayah Kampung Naga sudah menjadi tempat studi wisata oleh beberapa sekolah, mayoritas adalah sekolah yang berasal dari wilayah Jawa Barat dan Jakarta. Selain studi wisata, terdapat beberapa sekolah yang melakukan kunjungan ini sebagai proses visualisasi ilmu pengetahuan yang selama ini diperoleh siswa di kelas. Berikut adalah data pengunjung SMP pada bulan Februari 2013:Kearifan lokal masyarakat Kampung Naga juga telah dipergunakan sebagai sumber pembelajaran pada jenjang SMA. Salah satu SMA yang peneliti temui ketika hendak melakukan studi adalah MA Pembangunan UIN Jakarta yang mengusung tema kunjungan "Mengenal, Memahami, dan Memaknai Kearifan Lokal". Dalam kunjungan ini, siswa tidak hanya sekedar melihat, tetapi diberikan tugas untuk membuat karya ilmiah yang telah ditentukan.

Pada jenjang Sekolah Dasar (SD), hasil penelitian menunjukkan bahwa sudah terdapat kunjungan yang berasal dari jenjang ini, namun berasal dari luar kabupaten Tasikmalaya, yaitu dari Jakarta (SD Ar Rahman) dan Cianjur (SD Bayang Sempir), yang berkunjung pada bulan Februari 2013. Peneliti memperoleh data lebih lanjut melalui angket yang disebarkan kepada guru SD di wilayah Kabupaten Tasikmalaya. Hasil- nya adalah dari 37 guru SD yang disurvei, 33 setuju bahwa tradisi masyarakat Kampung Naga relevan dengan mata pelajaran IPS dan dapat menjadi sumber belajar di SD, meskipun ada 1 guru SD yang mengaku tidak mengetahui keberadaan masyarakat Kampung Naga. Namun ketika diberikan pertanyaan terkait eksistensi adat yang hidup di masyarakat Kampung Naga, 25 menyatakan setuju, sedangkan 8 tidak setuju. Berdasarkan penjelasan tersebut, ditemukan bukti bahwa eksistensi kearifan lokal masyarakat Kampung Naga yang populer di daerah lain, belum dimanfaatkan sebagai sumber belajar di sekolah sekitarnya.

\section{Nilai-nilai Kearifan Lokal Masyarakat Kampung Naga yang Relevan sebagai Sumber Belajar IPS SMP}

Berikut adalah nilai kearifan lokal yang hidup dalam masyarakat Kampung Naga.

a. Mencintai lingkungan, kecintaan masyarakat atas lingkungan tampak dengan adanya ketentuan "hutan larangan" dan tidak diperbolehkannya membuat ba ngunan melebihi batas yang sudah ditentukan oleh adat.

b. Kerjasama (gotong-royong), masyarakat Adat Kampung Naga selalu mengutama kan gotong royong antar warga apabila ada hajat yang diselenggarakan, misalnya renovasi masjid, pagar kampung, atau renovasi rumah warga.

c. Kebersamaan, ketika para pria melakukan kegiatan gotong royong, para wanita menyiapkan makanan. Beras dan lauk diambil dari kebun dan empang milik kampung, kemudian dimasak bersama dan disajikan ketika istirahat. Selain itu, kebersamaan tampak pada masih dikenalnya tradisi pamulang sambung.

d. Kesederhanaan dan Kesetaraan, penduduk Kampung Naga tidak mengingin kan adanya listrik, selain karena alasan bahan rumah yang mudah dibakar, juga karena adanya kekhawatiran masuknya listrik akan membuat hubungan kekerabatan warga menjadi memudar. Nilai kesetaraan tampak pada struktur rumah yang sama, pakaian dan gaya hidup yang 
Tabel 1. Data pengunjung jenjang SMP bulan Februari 2013

\begin{tabular}{lll}
\hline \multicolumn{1}{c}{ Nama Sekolah } & \multicolumn{1}{c}{ Tanggal Kunjungan } & \multicolumn{1}{c}{ Alamat } \\
\hline MTs Al Hidayah Sutron & 6 Februari 2013 & Sodonghilir, Tasik \\
SMP N 2 Pacet & 9 Februari 2013 & Pacet, Kab. Bandung \\
SMP N 10 Tasikmalaya & 10 Februari 2013 & Tasikmalaya \\
SMPN 1 Jamanis & 17 Februari 2013 & Tasikmalaya \\
SMP N 109 Jakarta & 24 Februari 2013 & Jakarta \\
SMP Angkasa & 24 Februari 2013 & Halim, Jakarta \\
\hline
\end{tabular}

Sumber: Buku Daftar Pengunjung Kampung Naga, 1 Februari 2013.

sama (tidak berbeda antara kuncen, RT, dan warga biasa).

e. Kemandirian, dalam pemenuhan kebutuhan untuk hidup sehari-hari, masyarakat Kampung Naga tidak bergantung pada bantuan pemerintah. Mereka memiliki prinsip "apabila diberi ya diterima, jika tidak, itu bukan masalah".

f. Kreatif, bentuk kreativitas tersebut adalah aneka kerajinan tangan yang diproduksi, baik untuk kebutuhan sendiri ataupun dijual pada wisatawan, membuat pupuk cair sendiri, dan mengolah lahan dengan kemiringan 15 derajat de ngan sistem terasering.

g. Tanggungjawab, sebagai warga adat de ngan mematuhi segala aturan adat, tanggungjawab sebagai seorang muslim juga tampak dengan selalu diadakannya kegiatan jamaah di masjid kampung, serta tanggungjawab sebagai warga masyarakat yaitu ikut serta dalam mematuhi ber- bagai aturan pemerintah.

h. Konsisten dan Berprinsip, penduduk tetap hidup dengan sederhana, tampak dalam aktivitas dan penggunaan sarana prasarana untuk menunjang kehidupan sehari-hari, meskipun saat ini sudah tampak pengaruh dari dijadikannya Kampung Naga sebagai kawasan wisata, diantaranya adalah penggunaan $\mathrm{HP}$, penggunaan barang plastik, radio, dan terdapat empat rumah sudah menggunakan TV yang berasal dari tenaga surya.

Kearifan Lokal Masyarakat sebagai Alternatif Sumber Belajar IPS SMP

Berdasarkan kajian atas Kompetensi Inti dan Kompetensi Dasar pada kurikulum 2013, maka nilai-nilai dalam kearifan lokal masyarakat adat Kampung dapat diintegrasikan dalam Kompetensi Inti dan Kompetensi Dasar pada jenjang kelas VII dan VIII, berikut rinciannya. 
1. $1 . \quad$ Kelas VII

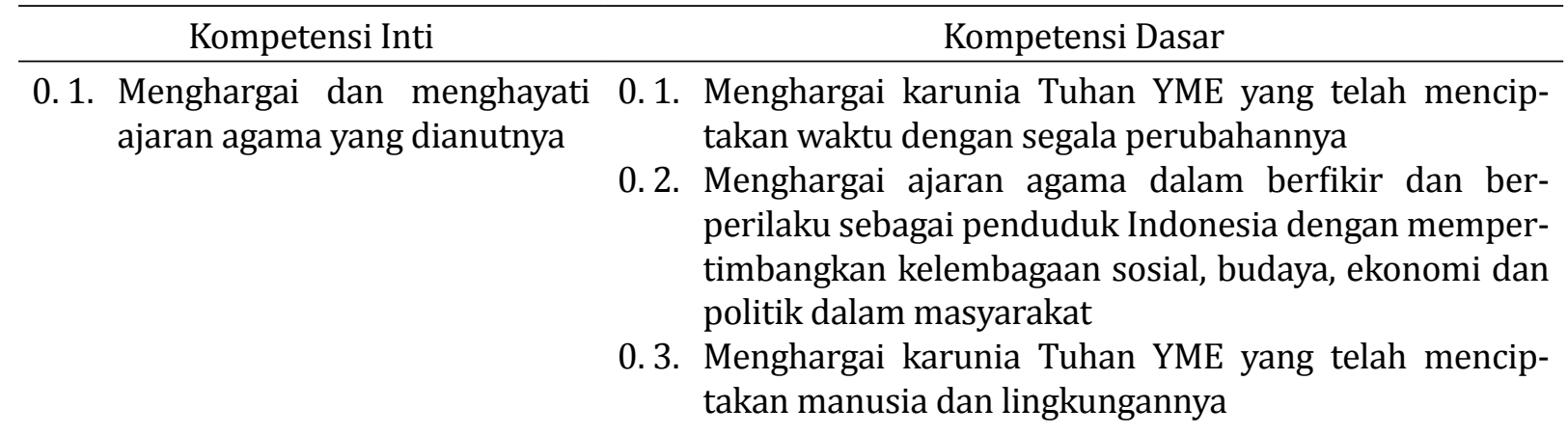

1. Menghargai dan menghayati perilaku jujur, disiplin, tanggungjawab, peduli (toleransi, gotong royong), santun, percaya diri, dalam berinteraksi secara efektif dengan lingkungan sosial dan alam dalam jangkauan pergaulan dan keberadaannya

1.1. Menunjukkan perilaku jujur, gotong royong, bertanggung jawab, toleran, dan percaya diri sebagaimana ditunjukkan oleh tokoh-tokoh sejarah pada masa lalu.

1. 2. Menunjukkan perilaku rasa ingin tahu, terbuka dan kritis terhadap permasalahan sosial sederhana.

1. 3. Menunjukkan perilaku santun, peduli dan menghargai perbedaan pendapat dalam interaksi sosial dengan lingkungan dan teman sebaya

2. Memahami pengetahuan (faktual, konseptual, dan prosedural) berdasarkan rasa ingin tahunya tentang ilmu pengetahuan, teknologi, seni, budaya terkait fenomena dan kejadian tampak mata

3. Mencoba, mengolah, dan menyaji dalam ranah konkret (menggunakan, mengurai, merangkai, memodifikasi, dan membuat) dan ranah abstrak (menulis, membaca, menghitung, menggambar, dan mengarang) sesuai dengan yang dipelajari di sekolah dan sumber lain yang sama dalam sudut pandang/teori

4. 3. Mencoba, mengolah, dan menyaji dalam ranah konkret (menggunakan, mengurai, merangkai, memodifikasi, dan membuat) dan ranah abstrak (menulis, membaca, menghitung, menggambar, dan mengarang) sesuai de ngan yang dipelajari di sekolah dan sumber lain yang sama dalam sudut pandang/teori 
1. 2 . Kelas VIII

\begin{tabular}{|c|c|}
\hline \multicolumn{2}{|r|}{ Kompetensi Inti } \\
\hline 1. & $\begin{array}{l}\text { Menghargai dan menghayati } \\
\text { perilaku jujur, disiplin, } \\
\text { tanggungjawab, peduli (toleransi, } \\
\text { gotong royong), santun, percaya diri, } \\
\text { dalam berinteraksi secara efektif } \\
\text { dengan lingkungan sosial dan alam } \\
\text { dalam jangkauan pergaulan dan } \\
\text { keberadaannya }\end{array}$ \\
\hline 2. & $\begin{array}{l}\text { Memahami dan menerapkan pe } \\
\text { ngetahuan (faktual, konseptual, } \\
\text { dan prosedural) berdasarkan rasa } \\
\text { ingin tahunya tentang ilmu penge- } \\
\text { tahuan, teknologi, seni, budaya ter- } \\
\text { kait fenomena dan kejadian tampak } \\
\text { mata }\end{array}$ \\
\hline
\end{tabular}

3. Mengolah, menyaji, dan menalar dalam ranah konkret (mengguna kan, mengurai, merangkai, memodi fikasi, dan membuat) dan ranah abstrak (menulis, membaca, menghitung, menggambar, dan mengarang) sesuai dengan yang dipelajari di sekolah dan sumber lain yang sama dalam sudut pandang/teori

4. 3 Menyajikan hasil pengamatan tentang bentukbentuk dan sifat dinamika interaksi manusia dengan lingkungan alam, sosial, budaya, dan ekonomi di lingkungan masyarakat sekitar

Mencermati relevansi tersebut, maka nilai-nilai kearifan lokal pada masyarakat Kampung Naga dapat menjadi alternatif sumber belajar IPS, terutama di wilayah Tasikmalaya, yang secara geografis berdekatan dengan daerah tersebut.

\section{SIMPULAN}

Masyarakat Adat Kampung Naga yang mendiami Kabupaten Tasikmalaya, merupakan salah satu masyarakat yang memiliki kearifan lokal yang muncul dalam aktivitas dan tradisinya. Kearifan lokal tersebut peneliti amati melalui tata kelola, sistem nilai adat, tata cara atau prosedur (adat), dan ketentuan khusus dalam masyarakat dalam hal ini terkait perlindungan dan pengelolaan lingkungan. Nilai-nilai yang muncul dalam kearifan lokal masyarakat Kampung Naga adalah mencintai lingkungan, gotong royong, kebersamaan, kesederhanaan dan kesetaraan, interaksi sosial, kreatif, kemandirian, tanggung jawab, dan berprinsip. Nilai-nilai tersebut cocok dengan KI dan KD pada kelas VII dan kelas VIII. Dengan demikian, kearifan lokal masyarakat adat Kampung Naga dapat 
menjadi sumber pembelajaran alternatif bagi siswa SMP, terutama dalam pelajaran IPS.

\section{UCAPAN TERIMA KASIH}

Ucapan rasa hormat dan terimakasih yang besar kami sampaikan kepada Lembaga Penelitian Universitas Muhammadiyah Prof. Dr. HAMKA (UHAMKA) atas kesempatan yang diberikan pada Kami untuk melanjutkan penelitian ini. Tidak lupa terimakasih Kami sampaikan pula kepada Dekan beserta jajarannya di FKIP UHAMKA dan Kaprodi Pendidikan Sejarah, atas izin yang diberikan untuk melakukan kegiatan penelitian, serta semua pihak yang telah membantu dilaksanakannya penelitian ini.

\section{DAFTAR PUSTAKA}

Atmodjo. 1986. Pengertian Kearifan Lokal dan Relevansinya dalam Modernisasi dalam Ayatrohaedi(1986). Kepribadian Budaya Bangsa (Local Genius). Jakarta: Dunia Pustaka Jaya.

Depdiknas. 2003. Undang-Undang RI Nomor 20, Tahun 2003, tentang Sistem Pendidikan Nasional.
Haditomo. 1989. Laporan Penelitian Sistem Sosial Kampung Naga. Fakultas Pendidikan Ilmu Pengetahuan Sosial IKIP Yogyakarta. Tidak Diterbitkan.

Sartini. 2006. Menggali Kearifan Lokal Nusantara Sebuah kajian Filsafati. http:// filsafat. ugm. ac. id, diakses tanggal $05 \mathrm{Juli}$ 2012.

Saringendyanti, Etty. "Kampung Naga, Tasikmalaya dalam Mitologi: Upaya Memaknai Warisan Budaya Sunda". http://pustaka. unpad. ac. id/. diunduh pada 30 Juni 2012.

Sulistiono, Budi. 1997. Laporan Penelitian Nilai-nilai Budaya Masyarakat di Kampung Naga. Jakarta: IAIN Syarif Hidayatullah. Tidak diterbitkan.

T. V, Savage dan D. G. Amstrong. 1996. Effective teaching in elementary social studies (third edition). New Jersey: Prentice Hall. 